\title{
RELATION BETWEEN APPLE-TREE YIELD SELF-REGULATION AND METEOROLOGICAL CONDITIONS DURING FRUIT SET
}

\author{
Aurelijus STARKUS, Institute of Horticulture, Lithuanian Research Centre for Agriculture and Forestry, Kaunas st. 30, Babtai, LT- \\ 54333, Kaunas dist., Lithuania, a.starkus@1sdi.lt (coresponding author) \\ Dalia GELVONAUSKIENĖ, Institute of Horticulture, Lithuanian Research Centre for Agriculture and Forestry, Kaunas st. 30 , \\ Babtai, LT-54333, Kaunas dist., Lithuania, d.gelvonauskiene@1sdi.lt \\ Birutė FRERCKS, Institute of Horticulture, Lithuanian Research Centre for Agriculture and Forestry, Kaunas st. 30, Babtai, LT- \\ 54333, Kaunas dist., Lithuania, b.frercks@1sdi.lt \\ Vidmantas BENDOKAS, Institute of Horticulture, Lithuanian Research Centre for Agriculture and Forestry, Kaunas st. 30, Babtai, \\ LT-54333, Kaunas dist., Lithuania, v.bendokas@1sdi.lt \\ Audrius SASNAUSKAS, Institute of Horticulture, Lithuanian Research Centre for Agriculture and Forestry, Kaunas st. 30, Babtai, \\ LT-54333, Kaunas dist., Lithuania, a.sasnauskas@1sdi.lt \\ Vidmantas STANYS, Institute of Horticulture, Lithuanian Research Centre for Agriculture and Forestry, Kaunas st. 30, Babtai, LT- \\ 54333, Kaunas dist., Lithuania, v.stanys@1sdi.1t
}

\begin{abstract}
Apple has a tendency to bear huge amount of flowers or inflorescences. Plants have ability to eliminate excess number of fruitlets. Frequently fruit trees eliminate insufficient number of fruitlets to grow good quality fruits. Most processes related to yield selfregulation varies significantly between different apples varieties. Also meteorological conditions influenced flower buds differentiation and fruit growth during blooming and other development stages. The investigations were carried out in $2015-2016$ at the Institute of Horticulture. The main aim was to evaluate yield self-regulation peculiarity in various apple varieties in different meteorological conditions. In our experiment we made fruit self - thinning evaluation of 15 different varieties. Meteorological conditions were varying. In 2015 there was lack of rainfall, while 2016 year was rainy. After each fruit-drop period the number of developed and undeveloped seeds were counted of self-sheded and normally growing fruits. Amount of developed seeds as auxins source is one of the most important factor for yield self-regulation. Varieties of apple which are blooming abundantly and eliminate high amount of fruitlets, grows fruits until maturity with stabile amount of developed seeds and produces permanent harvest annually, independently from meteorological conditions during vegetation. Such apple varieties need higher amount of developed seeds to inhibit abscission. Apple varieties tended to bloom abundantly and eliminate small amount of fruitlets depending on meteorological conditions. Demand of auxins to carry fruits depends on meteorological conditions therefore these apple-trees develop different amount of seeds, when weather conditions changes. We may presume, that different apple varieties need different amount of phytohormones or their ratio to hold fruitlets on the apple. Therefore apple trees with smaller amount of seeds in fruits grow more fruits to its normal size.
\end{abstract}

Keywords: auxins; fruitlet absision; Malus x domestica, meteorological conditions, seeds development.

\section{INTRODUCTION}

Apple (Malus x domestica Borkh.) is a widely grown fruit tree in the world, most commonly distributed in the temperate zone. From an economic point of view, apple is one of the most important fruit-trees (Ackerman, Samach, 2015). The purpose of intensive horticulture is to produce a consistent, high quality harvest. Agrotechnical technologies and meteorological conditions determine quality of the fruit.

Apple-trees forms a large amount of flowers and fruitlets. After flowering, a transformation in fruit-tree occurs: the flowers become fruitlets (Rodrigo et al. 2000; Lauri et al. 1996). Only 5-10\% of these fruitlets grows to normal fruit size. The rest of the fruits grow small and are poor in quality. Therefore, regulation of the amount of flowers and fruits of the plant to the optimum quantity is important in intensive horticulture (Kviklienė, 2008). On this purpose, manual or chemical thinning methods are used (Williams, 1980; Miller, 1988; Denis, 2000). As alternative, new apple varieties can be created, with ability to self-reduce amount of flowers or fruitlets to the optimal amount (Celton et al., 2014).

Plants has ability to eliminate undeveloped or mature organs (flowers, fruitlets, leaves) in their different organogenesis stages. Separation of plant organs is a natural process (Bangerth, 2000; Dal Cin et al., 2009). This phenomenon is very important as it determines yield of the tree and fruit quality. The apple-trees eliminate fruitlets during

Copyright (C) 2017 The Authors. Published by Aleksandras Stulginskis University. This is an open-access article distributed under the terms of the Creative Commons Attribution License (CC-BY 4.0), which permits unrestricted use, distribution, and reproduction in any medium, provided the original author and source are credited. 
3 development stages: 1 - several days after flowering - unpollinated flowers are shedding; 2 - before intensive fruit growth (in July); 3 - before fruit maturity (Unitiedt, Blanke, 2001; Dal Cin et al., 2009). Natural thinning of flowers and inflorescence to the optimal level is not a common feature. Only a few apple varieties are known, which can naturally reduce fruitlets to the one fruit in inflorescence (Lespinasse, 1992). Apple varieties differ in many processes which are related to yield self-regulation. It has been observed that trees of different apple varieties vary in intensity of flowering and elimination of fruitlets (Lespinasse, 1992; Lauri et al., 1995; Lauri et al., 1997).

One of the conditions for the development of fruits is sufficient amount of seeds, where phytohormone auxin is produced. Auxin is natural substance essential for normal fruit development (Preece, Read, 2005). Quality of flower pollination has a decisive influence on seed development, fruit size and quality (Monzón at al., 2004; Stern et al., 2007; Theron, 2011). The quality of apple flower pollination mainly depends on the activity of insect pollinators during flowering period (Quinet, Jacuemart, 2017). conditions.

Our aim was to evaluate peculiarity of yield self-regulation in various apple varieties in different meteorological

\section{MATERIAL AND METHODS}

The research was carried out in period of 2015 - 2016 at Institute of Horticulture, Lithuanian Research Centre for Agriculture and Forestry (Babtai, Kaunas district), in apple gene pool collection, which was planted in 2000-2004. Apple trees grafted on rootstock B118 were investigated. Scheme of plating for fruit trees - 5 x 3 m. According to multi-year observations data, 15 contrast apple varieties were selected for research, and these varieties were divided into 2 contrasting groups according to flowering abundance and fruit dropping (Starkus et al., 2017) (Table 1).

Table 1. Division of apple varieties according fruitlet elimination and their origin.

\begin{tabular}{|c|c|c|c|}
\hline No. & Characteristic of apple-tree variety's groups & Apple-tree variety & Origin \\
\hline 1. & \multirow{11}{*}{$\begin{array}{l}\text { I group. Apple-trees bloom abundantly, eliminate high } \\
\text { amount of fruitlets. }\end{array}$} & 'Orlovim' & Russian \\
\hline 2. & & 'Selena' & Czech \\
\hline 3. & & 'Macresa' & Czech \\
\hline 4. & & 'Otava' & Czech \\
\hline 5. & & 'Montvilinis' & Lithuania \\
\hline 6. & & 'McIntosh Spur E' & Canada \\
\hline 7. & & 'Sonata' & Unknown \\
\hline 8. & & 'Voschod' & Russia \\
\hline 9. & & 'Lord Lambourne' & Great Britany \\
\hline 10. & & 'Melroze' & JAV \\
\hline 11. & & 'Kaunis' & Lithuania \\
\hline 12. & \multirow{4}{*}{$\begin{array}{l}\text { I group. Apple-trees bloom abundantly, eliminate small } \\
\text { amount of fruitlets. }\end{array}$} & 'Geltonasis arkadas' & Russia \\
\hline 13. & & 'Oswald' & Unknown \\
\hline 14. & & 'Discovery' & Great Britany \\
\hline 15. & & 'Albrecht apfel' & Germany \\
\hline
\end{tabular}

Meteorological conditions. Winters of 2015-2016 years were favourable for apple-trees. Meteorological conditions during experiment years considerably differed. Compared to the multiannual data, 2015 years were droughty and 2016 were rainy. Meteorological conditions were favourable during blooming period in 2015 year. The amount of rainfall was close to the multiannual average, temperature was $2{ }^{\circ} \mathrm{C}$ lower. In 2016 , the amount of rainfall was twice higher than during blooming period of 2015 year, and amount of rainfall was higher by $31.3 \mathrm{~mm}$. June of 2015 years was droughty, amount of rainfall was lower by $46.2 \mathrm{~mm}$ than usual, and in 2016 amount of rainfall was higher by $21 \mathrm{~mm}$ in June. In July of 2015, the temperature and amount of rainfall were close to the multiannual average. July of 2016, was rainy, amount of rainfall was higher than usual by $82 \mathrm{~mm}$. August of 2015 was dry, amount of rainfall was lower than usually by $44 \mathrm{~mm}$, and in August of 2016, the amount of rainfall was higher by $35 \mathrm{~mm}$ than multiannual average.

During the experiment, these evaluations were carried out:

Assessment of fruitlets self-shedding dynamics. During the massive blooming, branches of trees with 100 inflorescences were selected and marked (25 inflorescences per replication). During vegetation period, changes in amount of blooms, fruitlets and inflorescences were evaluated. Evaluations were carried out 4 times: 1 - during mass blooming (when about $80 \%$ of buttons blooms), the initial number of blooms per 100 inflorescences was estimated; 2 - after the elimination of unpollinated blooms. 3 - after second fruitlet elimination - middle of July; 4 - before fruit maturity (end of August- beginning of September, depending on the variety).

Assessment of the seed development in fruitlets. Number of developed and undeveloped seeds was established in 12 self-shaded and normally growing fruits collected after elimination of fruitlets in June and later. The fruits were cut in half, avoiding damaging the seeds inside. After cutting, the seeds were removed, divided into undeveloped (significantly lagging in size from other, collapsed or those which only visible rudimentals) and normally developed - seeds in size and shape similar to full developed. Developed, undeveloped and total amount of seeds was evaluated.

The experiments were performed in 4 replications. Repetition - 1 apple tree.

Data was evaluated using Microsoft Excel - averages and standard errors was calculated. 


\section{RESULTS AND DISCUSSION}

Dynamics of fruitlet self-elimination in different apple variety groups was studied. It was established, that fruittrees belonging to different groups eliminated fruitlets at irregular intensiveness in 2015-2016 years (Fig.1). in June, after elimination of unpollinated blooms apples belonging to first group which are tended to bloom abundantly and eliminate high amount of fruitlets, had 31,9 fruitlets per 100 blooms, which were marked during mass blooming. Meanwhile, apple varieties belonging to the second group, which blooms abundantly and eliminates small amount of fruitlets, eliminated smaller amount of fruitlets at the same time. In this case 41.6 fruitlets were counted per 100 blooms. In 2016 years, when meteorological conditions were unfavourable, the same tendency was observed: in first group 27.6 fruitlets remained per 100 blooms; while 50.8 fruitlets per 100 bloom remained in second group of apple varieties, that is higher number compared to 2015 year, with favourable for fruiting conditions. Significant differences in fruitlet self-elimination were determined between groups of apple varieties during earlier years.

Evaluation of remaining fruitlets amount after June - July fruitlet elimination revealed, that significant amount of fruitlets was eliminated. Tendencies of fruitlets elimination remained similar between different apple variety groups. First group's apple varieties had similar amount of fruitlets after second fruit drop (July) during both experiment years: 12.2 in 2015 and 12.9 in 2016. Number of remaining fruitlets in varieties depending to second group varied: 16.3 fruitlets in 2015 year, and 18.3 in 2016.

First group apple varieties had 10.3 fully developed fruits per 100 blooms, while varieties from second group developed 8.8 fruits in 2015 year, however no reliable differences were identified. In 2016 year, when meteorological conditions were unfavourable during blooming period, apple varieties from first group had 8.9 fully developed fruits. Number of fully developed fruits reached 17.1 in varieties from the second group that means apple varieties belonging to the second group developed significantly higher amount of fruits than apple varieties from first group.

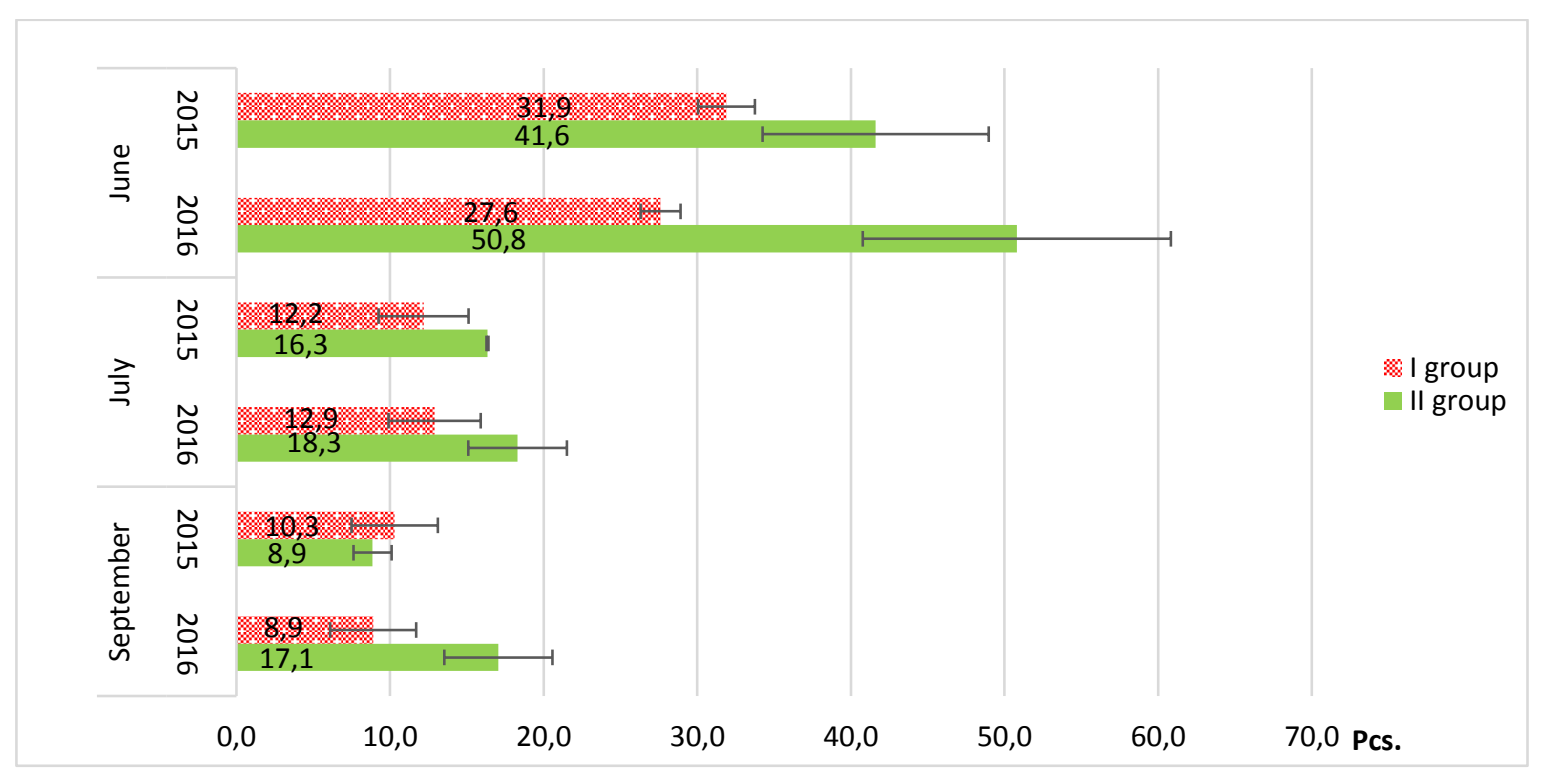

Figure 1. The dynamics of changes in remaining fruitlets amount in apple varieties belonging to different groups according their yield self-regulation characteristics (2015 - 2016 average data of varieties belonging to groups).

After the blooming a transformation occurs in the fruit tree the flowers becomes fruit. The ability of the bloom to develop to a normal fruit is determined by a variety of factors, including genetic and morphological characteristics of variety, carbohydrate content, meteorological conditions (Rodrigo et al., 2000; Lauri et al. 1996). Research data reveals that deviation from optimal temperature during blooming period had significant effect on fruit-drop. The largest number of blossoms were dropped when temperature was higher than $20^{\circ} \mathrm{C}$. Lower temperatures $\left(5^{\circ} \mathrm{C}, 10^{\circ} \mathrm{C}, 15^{\circ} \mathrm{C}\right)$ didn ${ }^{\prime} \mathrm{t}$ reveal such effect. Changes in temperature had different effect on various apple varieties. Low temperature during blooming period reduced number of fruit-drop (Tromp and Borsboom, 1994). According to N. Albuquerque researchers the abundance of blooms and their density on the branch didn`t differ in same varieties during different years. The differences were found only between varieties. It is known that high amount of flowers or fruitlets is not favourable for optimal fruit yield. Trees which are tended to form abundant number of fruitlets use nutrients for non-productive fruitlets development. This cause overthinking of fruitlets (Racskó, 2008).

Analysis of seed development in fruits of different apple varieties revealed, that second group apple trees, which tend to have higher amount of fruits had lower amount of normally developed seeds, than first group apple varieties, when meteorological conditions were favourable (Table 2). $5.85-5.67$ normally developed seeds were counted in fruits of second apple varieties group, while in first group the amount of normally developed seeds was 7.26 - 7.54 during June July of 2015. That means first group apple varieties had statistically larger amount of normally developed seeds per fruit than varieties belonging to the second group, however such tendency wasn't observed during unfavourable meteorological 
conditions. There were no differences in seed number in fruits between varieties from first and second groups. During June and July the average amount of seeds was 7.30 and 7.58 pcs. (first group) and 8.25 and 7.76 pcs. (second group).

Table 2. Amount of seeds in picked fruits of apple varieties grouped according to their yield self-regulation characteristics (2015 - 2016 average data of varieties belonging to groups).

\begin{tabular}{|c|c|c|c|c|c|}
\hline \multirow{3}{*}{ Apple variety group } & \multicolumn{2}{|c|}{2015} & \multicolumn{3}{|c|}{2016} \\
\hline & \multicolumn{5}{|c|}{ Amount of normally developed seeds, pcs. } \\
\hline & June & July & June & & July \\
\hline I group & $7.26 \pm 0.28$ & $7.54 \quad \pm 0.32$ & $7.30 \pm 0.56$ & 7.58 & \pm 0.34 \\
\hline II group & $5.85 \pm 0.45$ & $5.67 \pm 0.43$ & $8.28 \pm 0.77$ & 7.76 & \pm 0.72 \\
\hline \multirow[t]{2}{*}{ Apple variety group } & \multicolumn{5}{|c|}{ Amount of undeveloped seeds, pcs. } \\
\hline & June & July & June & & July \\
\hline I group & $0.90 \quad \pm 0.38$ & $1,02 \pm 0.34$ & $0.58 \quad \pm 0.17$ & 2.47 & \pm 0.37 \\
\hline II group & $2.60 \pm 0.28$ & $1.24 \pm 0.28$ & $1.72 \pm 1.0$ & 2.59 & \pm 0.74 \\
\hline
\end{tabular}

2015 June second group of apple varieties had significantly higher amount of undeveloped seeds per fruit (2.60 pcs) than varieties from first group $(0.90 \mathrm{pcs})$ in June 2015 . Significant differences were also observed in varieties belonging to second group during different months: In 2015 June apple trees grew fruitlets with average 2.60 undeveloped seeds. During the second fruit drop (July), these fruitlets were eliminated and amount of undeveloped seeds in fruits were significantly lower (1.24 pcs.). In this growing stage amount of undeveloped seeds became similar comparing first and second groups, respectively 1.02 and 1.24 undeveloped seeds. In June of 2016 year significant differences between groups were observed. Fruits of apple varieties from first group had 0.58 undeveloped seeds and 1.72 from second group. Later, after second fruitlet drop in July both apple variety groups had essential larger amount of undeveloped seeds - 2.47 in fruits of first group and 2.59 in the second.

The results of our research show that, first group of apple varieties grew fruits with $7.26-7.58$ developed seeds independent from meteorological conditions during vegetation period. Probably such amount of seeds will ensure sufficient amount of auxins necessary for the development of the fruits. This could be determined by genetic factors ensuring constant yield. Adaptation level of second apple varieties group under unfavourable meteorological conditions is unstable: trees grow fruits with more than 7 developing seeds when meteorological conditions are unfavourable. Meanwhile when meteorological conditions were favourable, amount of seeds was lower (5.85 and 5.67). This could mean that apple varieties from second group needs lower amount of auxin when meteorological conditions are favourable, and higher level of auxins must be ensured by larger amount of developing seeds under unfavourable meteorological condition.

Table 3. Amount of seeds in self-shedded fruits of apple varieties grouped according to their yield self-regulation characteristics (2015 - 2016 average data of varieties belonging to groups).

\begin{tabular}{|c|c|c|c|c|}
\hline \multirow{3}{*}{ Apple-tree variety group } & \multicolumn{2}{|c|}{2015} & \multicolumn{2}{|c|}{2016} \\
\hline & \multicolumn{4}{|c|}{ Amount of normally developed seeds, pcs. } \\
\hline & July month & June month & July month & June month \\
\hline I group & $0.00 \quad \pm 0.00$ & $1.27 \quad \pm 0.89$ & $0.06 \quad \pm 0.22$ & $1.33 \pm 0.54$ \\
\hline II group & $0.56 \quad \pm 0.42$ & $0.1 \quad \pm 0.12$ & $0.27 \quad \pm 0.04$ & $2.05 \pm 0.80$ \\
\hline \multirow[t]{2}{*}{ Apple-tree variety group } & \multicolumn{4}{|c|}{ Amount of undeveloped seeds, pcs. } \\
\hline & July month & June month & July month & June month \\
\hline I group & $8.38 \pm 1.26$ & $7.90 \pm 1.18$ & $6.98 \pm 0.65$ & $6.46 \pm 0.19$ \\
\hline II group & $6.98 \pm 0.58$ & $5.80 \quad \pm 1.05$ & $7.63 \pm 1.40$ & $7.52 \pm 2.12$ \\
\hline
\end{tabular}

Evaluation of seed number in self-sheded fruit revealed, that eliminated fruits had small amount of normally developing seeds (Table 3). In 2015 during first fruitlet elimination period there were no normally developing seeds in self-sheded fruits of varieties, belonging to first group. Second group fruits had 0.56 developing seeds. In July, first group apple fruits had much more developing seeds (1.27 pcs.), than second group ( 0.10 pcs.). Compared to early assessment period this group had significantly higher amount of developing seeds. In second group there were no significant differences between evaluation periods.

In June of 2016 year similar amount of developing seeds was observed in different apple variety groups: in first group there were average 0.06 seed in second -0.27 seeds. Similar to previous year in July a significant higher amount of developing seeds was counted in both groups of eliminated apple-tree fruits. In first variety group there were 1.33 developing seeds, in second - 2.05. No differences between groups were identified, however in second groups differences were established between evaluation years.

Eliminated fruits distinguished in high amount of undeveloped seeds. Both groups in all evaluation periods showed this tendency. No differences were observed between groups or years of evaluation. We may state, that during first fruitlet elimination period only inferior fruitlets with small amount of developing seeds are eliminating. When the second fruit drop begins, apple varieties belonging to the first group eliminates excess fruitlets with fair amount of seeds. Second 
group apple varieties eliminates only fruitlets with considerably lower amount of developing seeds. When meteorological conditions are unfavourable, no differences between apple variety groups may be found.

The amount of seeds in the fruit and their development during the initial stages of growth have a close relationship with premature fruit drop (Luckwill, 1970). Seeds, especially their endosperm, are the site of synthesis, where growth substances are produced. When then endosperm is formed, the fruit start growing intensely, under effect of auxin. After the embryo have completed its growth the formation of secondary endosperm appears, which continues to produce auxin, inhibiting fruit abscission (Wareing and Phillips, 1978). J. Racskó with co-authors (2008) determined relationship between premature fruit drop and amount of developed seeds in fruit. Fruits with the lowest amount of developed seeds are shedding first (Racskó et al., 2007). According to B. Teskey and J. Shoemaker (1978), apple fruits with up to 3 normally developed seeds are falling first.

\section{CONCLUSIONS}

One of the most important factor for yield self-regulation is the amount of developed seeds as auxins source in fruit. Varieties of apple which are blooming abundantly and eliminate high amount of fruitlets, grows fruits until maturity with stabile amount of developed seeds and produces permanent harvest annually, independently from meteorological conditions during vegetation. Apple tends to bloom abundantly and eliminate small amount of fruitlets depending on meteorological conditions. Fruit development is greatly determined by amount of developed seeds.

\section{REFERENCES}

1. Ackerman, M., Samach, A. 2015. Daubts regarding carbohydrates shortage as a trigger toward abscission of specific Apple (Malus domestica) freuitlets. New Negatives in Plant Science, Vol. 1-2, pp. 46-52. https://doi.org/10.1016/j.neps.2015.06.003

2. Alburquerque, N., Burgos, L., Egea, J. 2004. Influence of flower bud density, flower bud drop and fruit set on apricot productivity. Scientia Horticulturae, Vol. 102, Iss. 4, pp. 397-406. https://doi.org/10.1016/j.scienta.2004.05.003

3. Bangerth, F. 2000. Abscission and thinning of young fruit and their regulation by plant hormones and bioregulators. Plant Growth Regulation, 31: 43-59. https://doi.org/10.1023/A:1006398513703

4. Celton, J.M., Kelner, J.J., Martinez, S., Bechti, A., Khelifi, T.A., James, M.J. 2014. Fruit self-thinning: a trait to consider for genetic improvement of apple tree. PLoS One, Vol. 9, pp. 910-916. https://doi.org/10.1371/journal.pone.0091016

5. Dal Cin, V., Barbaro, E., Danesin, M., Murayama, H., Velasco, R. 2009. Fruitlet abscission: a cDNA-AFLP approach to study genes differentially expressed during shedding of immature fruits reveals the involvement of a putative auxin hydrogen symporter in apple (Malus domestica L. Borkh). Gene, Vol. 442, pp. 26-36. ttps://doi.org/10.1016/j.gene.2009.04.009

6. Denis, F. G. 2000. The history of fruit thinning. Plant Growth Regulation, Vol. 31, pp. 1-16. https://doi.org/10.1023/A:1006330009160

7. Kviklienè, N., 2008. Cheminio užuomazgų retinimo ịtaka 'Lodel' obelų vaisių kokybei. Sodininkystè ir daržininkystė, Vol. 26, No. 1, pp. 22-28. [In Lithuanian]

8. Lauri, P. E., Terouanne, E., Lespinasse, J. M. 1997. Relationship between the early development of apple fruiting branches and the regularity of bearing - An approach to the strategies of various cultivars. Horticultural Science, Vol. 72, pp. 519-530. https://doi.org/10.1080/14620316.1997.11515539

9. Lauri, P. E., Terouanne, E., Lespinasse, J. M., Regnard, J. L., Kelner, J. J. 1995. Genotypic differences in the axillary bud growth and fruiting pattern of apple fruiting branches over several years - An approach to regulation of fruit bearing. Scientia Horticulturae, Vol. 64, pp. 265-281. https://doi.org/10.1016/0304-4238(95)00836-5

10. Lauri, P. E., Terouanne, E., Lespinasse, J. M. 1996. Quantitative analysis of relationships between inflorescence size, bearing-axis size and fruit-set. An apple tree case study. Annals of Botany, Vol. 77, pp. 277-286. https://doi.org/10.1006/anbo.1996.0031

11. Lespinasse, Y. 1992. Le pommier. Amémioration des espèces végétales cultivées, objectifs et critères de sélection, 579-594.

12. Luckwill, L. C. 1970. The control of growth and fruitfulness in the apple trees. In: Physiology of Tree Crops. Academic Press Inc., London, pp. 232-254.

13. Mille, S. S. 1988. Plant bioregulators in apple and pear culture. Horticultural Reviews, Vol. 10: pp. $309-401$. https://doi.org/10.1002/9781118060834.ch9

14. Monzón, V.H., Bosch, J., Retana, J., 2004. Foraging behavior and pollinating effectiveness of Osmia cornuta (Hymenoptera: Megachilidae) and Apis mellifera (Hymenoptera: Apidae) on Comice pear. Apidologie, Vol. 35, pp. 575-585. https://doi.org/10.1051/apido:2004055

15. Preece, L.E., Reed, P.E. 2005. The Biology of Horticulture, 2rd ed., Wiley, New York.

16. Quinet, M., Jacquemart, A.L., 2017 Cultivar placement affects pollination efficiency and fruit production in European pear (Pyrus communis) orchards. European Journal of Agronomy, Vol. 91, pp. 84-92. https://doi.org/10.1016/j.eja.2017.09.015

17. Racskó, J., Leite, G. B., Petri, J. L., Zhongfu, S., Wang, Y., Szabó, Z., Soltész, M., Nyéki, J. 2007. Fruit drop: The role of inner agents and environmental factors in the drop of flowers and fruits. International Journal of Horticultural Science, Vol. 13, Iss. 3, pp. 13-23.

18. Racskó, J. 2008 Crop autoregulation of apple on different growth inducting rootstock: abstact of PhD thesis. Debrecen.

19. Rodrigo, J., Hormaza, J. I., Herrero, M. 2000. Ovary starch reserves and flower development in apricot (Prunus armeniaca). Physiologia Plantarum, Vol. 108, pp. 35-41. https://doi.org/10.1034/j.1399-3054.2000.108001035.x

20. Starkus, A., Gelvonauskienè, D., Sasnauskas, A., Stany, V. 2017 Parametrai naminès obels veislių žydèjimui ir užuomazgų išsiretinimui charakterizuoti. Sodininkystè ir daržininkystè, Vol. 36, No. 1-2, pp. 15-29. [In Lithuanian] 
21. Stern, R.A., Sapir, G., Shafir, S., Dag, A., Goldway, M., 2007. The appropriate management of honey bee colonies for pollination of Rosaceae fruit trees in warm climates. Middle East. Russ. Journal of Plant Science and Biotechnology, Vol. 1, pp. $13-17$.

22. Teskey B. J., Shoemaker. 1978. Apples. Springer, US, pp. 1-126.

23. Theron, K.I., 2011. Size Matters: factors influencing fruit size in pear. Acta Horticulturae, Vol. 909, pp. 545-556. https://doi.org/10.17660/ActaHortic.2011.909.65

24. Tromp, J., Borsboom, O. 1994. The effect of autumn and spring temperature on fruit set and on the effective pollination period in apple and pear. Scientia Horticulturae, Vol. 60, Iss. 1-20, pp. 23-30.

25. Untiedt, R., Blanke, M. 2001. Effects of fruit thinning agents on apple tree canopy photosynthesis and dark respiration. Plant Growth Regulation, Vol. 35, Iss. 1, pp. 1-9. https://doi.org/10.1023/A:1013894901621

26. Wareing, P.F., Philip,s J.D.J. 1978. The control of growth and differentiation in plants. 2nd Edition. Pergamon Press. New York.

27. Williams, R.R. 1980 Control of premature fruit drop in Macadamia integrifolia: effects of naphthalene acetic acid application, cincturing, and shoot-tip removal. Australian Journal of Experimental Agriculture and Animal Husbandry, Vol. 20, No. 107, pp. 740-742. ttps://doi.org/10.1071/EA9800740 